\title{
Estimated phyllochron in low tunnel cultivated strawberry cultivars
}

\section{Estimativa de filocrono em cultivares de morangueiro conduzidas em túnel baixo}

\author{
Kassia Luiza Teixeira Cocco ${ }^{\mathrm{I}}$ Denise Schmidt ${ }^{\mathrm{II}}$ Braulio Otomar Caron ${ }^{\mathrm{II}}$ Velci Queiroz de Souza \\ Daniele Cristina FontanaII Gizelli Moiano de Paula ${ }^{I I}$
}

\section{ABSTRACT}

The aim of this study was to determine phyllochron in strawberry cultivars, from two origins during two crop years, conducted in low tunnel. Experiments were conducted at the Universidade Federal de Santa Maria, campus Frederico Westphalen (CESNORS/UFSM), Brazil, evaluating 'Camarosa', 'Camino Real' and 'Albion' strawberry cultivars. During the 2012 crop year, seedlings from Chile and Pelotas/RS, Brazil were evaluated, for the 2013 crop year, only seedlings from Chile were submitted to evaluations. In order to determine the phyllochron, twice a week the numbers of leaves (NL) of the main crown were counted and a regression between $N L$ and accumulated thermal time (ATT) was held. The experimental design was a complete randomized block, with three repetitions with the evaluation of 12 plants per experimental unity, consisting of a factorial. For 2012 and 2013 crop years, it is possible to conclude that 'Camarosa' and 'Camino Real' cultivars required higher accumulation of degreedays $\left({ }^{\circ} \mathrm{C}\right.$ day $\left.^{-1}\right)$ to issue each successive leaf than $\mathrm{cv}$. 'Albion', which, in turn, presented higher rates of leaf emergence, being considered earlier. Regarding to origin, seedlings from $\mathrm{cv}$. 'Albion' from Chile presented lower total phyllochron values and for samples from Pelotas, no difference among cultivars was observed.

Key words: Fragaria $x$ ananassa, leaf appearance, number of leaves, temperature, thermal time.

\section{RESUMO}

O objetivo deste trabalho foi determinar o filocrono, em cultivares de morangueiro, de duas procedências e em dois anos agricolas, conduzidas em túnel baixo. Os experimentos foram conduzidos em área da Universidade Federal de Santa Maria, campus Frederico Westphalen (CESNORS/UFSM), constando da avaliação das cultivares 'Camarosa', 'Camino Real'e 'Albion'. Para o ano de 2012, avaliaram-se mudas procedentes do Chile e da região de Pelotas/RS e, para o ano de 2013, apenas mudas chilenas. Na determinação do filocrono, foi realizada contagem, duas vezes por semana, do número de folhas (NF) da coroa principal e, posteriormente, realizou-se regressão linear entre o $\mathrm{NF}$ e a soma térmica acumulada (STa). O delineamento experimental foi o de blocos casualizados, com três repetições, sendo cada unidade experimental composta por 12 plantas de avaliação, em esquema fatorial. Para os anos de 2012 e 2013, os resultados obtidos mostram que as cultivares 'Camarosa'e 'Camino Real' necessitam de maior acúmulo de graus dia para emissão de cada folha sucessiva do que a cv. 'Albion', que, por sua vez, apresenta maiores taxas de emissão de folhas, podendo ser considerada como mais precoce. Com relação à procedencia, verifica-se que as mudas da cv. 'Albion' provenientes do Chile apresentam menores valores de filocrono total. Para a procedência Pelotas, não foi observada diferença entre as cultivares.

Palavras-chave: Fragaria x ananassa, emissão de folhas, número de folhas, temperatura; soma térmica.

\section{INTRODUCTION}

The strawberry is a vegetable, popularly known as a fruit vegetable. It is appreciated in different regions of the world and, according to OLIVEIRA \& SCIVITTARO (2009), the world yield is about 3.1 millions of tons. The Rio Grande do Sul state is one of the Brazilian states with tradition of

\footnotetext{
'Programa de Pós-graduação em Fisiologia Vegetal, Departamento de Botânica, Universidade Federal de Pelotas (UFPEL), CP 354, 96010-900, Pelotas, RS, Brasil. E-mail: kassiacocco@hotmail.com. Corresponding author.

IIDepartamento de Ciências Agronômicas e Ambientais, Universidade Federal de Santa Maria (UFSM), Campus Frederico Westphalen,

Frederico Westphalen, RS, Brasil.

III Universidade Federal do Pampa (UNIPAMPA), Campus de Dom Pedrito, Dom Pedrito, RS, Brasil. 
growing strawberries, being the third highest grower in Brazil, producing about 18,000 tons.

Strawberry development is influenced by environmental factors, being air temperature and photoperiod the main factors that can affect the crop (SERÇE \& HANCOCK, 2005). Interaction between both can control flowering in short day cultivars and for neutral day cultivars; whereas, the flowering occurs continuously, when air temperature is between 10 and $28^{\circ} \mathrm{C}$ (SANTOS, 1999).

During the vegetative period, leaf development is characterized by new leaves and it is related to leaf area index, a physiological parameter that is used for plant growth analysis, because it affects sunlight interception during photosynthesis and the biomass production that will affect, indirectly, crop yield (STRECK et al., 2003; XUE et al., 2004; STRECK et al., 2005).

An excellent plant development measurement is the number of accumulated leaves (NL) on the main stem, that, when integrated in time, can provide the leaf emission speed (STRECK et al., 2003). Thus, it is possible to use the concept as a way to estimate leaf emission speed, since it is defined as a time between two consecutive leaf emissions in a stem or stalk, and its unity is time leaf ${ }^{-1}$ (KLEPPER et al., 1982).

The air temperature can be included in 'plant time' through the thermic time concept, in degree-day $\left({ }^{\circ} \mathrm{C}\right.$ day), being this temperature above the minimum or basal. For strawberries, the minimum temperature is $7^{\circ} \mathrm{C}$ and under this temperature, no development is observed, or the developments is so low that it is not considered for the calculations (McMASTER \& WILHELM, 1997).

According to literature, the period of time between growth of two consecutive leaves for strawberries is from 8 to 12 days, being the temperature a very important factor for this physiological process (GALLETA \& HIMELRICK, 1990; ROSA et al., 2011). The knowledge of thermal conditions for plant development is fundamental to optimize field management and improve fruit growth, determining, for each cultivar, the adequate place and period of time, in order to allow the correct and better plant biologic expression. The aim of this study was to determine phyllochron in low tunnel conducted strawberries cultivars from two origins and during two crop years.

\section{MATERIALS AND METHODS}

The research was conducted in an experimental area of the Universidade Federal de Santa Maria, Frederico Westphalen campi (CESNORS/UFSM), located at Frederico Westphalen - RS, Brazil, $27^{\circ} 23.728^{\prime \prime}$ S, 53 $25.749^{\circ}$ "O and at 493 meters of altitude. The climate of the region is humid subtropical - Cfa (KÖPPEN \& GEIGER, 1928). Soil has a clayley texture, well drained, deep to very deep, classified as a typical red alumino-ferric latosol (EMBRAPA, 2013).

The experimental design was a complete randomized block, with three repetitions with the evaluation of 12 plants per experimental unity. For the first experiment, sources of variation were: three cultivars (A) and two origins (B) - Chile and Pelotas, in a $3 \times 2$ factorial. For the second experiment, the evaluated sources of variation were cultivars (A) and years (B) - 2012 and 2013, also in a factorial scheme (3x2). For both experiments, the evaluated cultivars were 'Camarosa' and 'Camino Real' (short day) and 'Albion' (neutral day or indifferent to photoperiod).

The soil was prepared, for both experiments, with plowing followed by harrowing, with the plot (bed) construction. Correction of the fertility level was based on soil chemical analysis held in pre-planting. The necessary amount of nutrients for the crop was supplied by fertigation throughout the production cycle.

During the 2012 crop year, the experiment was conducted using seedlings produced in two origins: Rio Grande do Sul, Brazil (Pelotas region), which were transplanted to the field on May $19^{\text {th }}$, and imported seedlings from Chile, which were transplanted on June $5^{\text {th }}$. For the 2013 crop year, only seedlings from Chile were used, that were transplanted on May $19^{\text {th }}$ for 'Camarosa' and 'Camino Real' and June $21^{\text {st }}$ for 'Albion'.

After the seedlings cleaning, they were planting in a space of $0.30 \mathrm{~m} \times 0.30 \mathrm{~m}$ and the dimension of beds were 1.20 meters of width and 15.00 meters of length, in a low tunnel covered with an Anti-UV low density polyethylene with $150 \mu \mathrm{m}$ of thickness. Thirty days after seedlings planting, the drip irrigation system was installed using drip tapes and soil cover (mulching) with a black opaque polyethylene film, with a thickness of $50 \mu \mathrm{m}$. Other plant management and phytossanitary treatments were realized according to crop recommendations.

The number of leaves (NL) of the main crown was counted twice a week in 12 plants per plot, from leaf emission to the end of the experiment, considering leaf emission when the leaf was visible, with more than 1.00 centimeter of length. The maximum and minimum temperature were daily registered at the Frederico Westphalen's weather 
station named 'Estação Meteorológica de Observação de Superfície Automática' that is from the Instituto Nacional de Meteorologia (INMET), located about 30 meters from the place that the experiment was carried out. The equation proposed by ARNOLD (1960) and GILMORE \& ROGERS (1958) was used for calculations of daily thermic time (DTT), expressed in ${ }^{\circ} \mathrm{C}$ day $^{-1}$. The mean daily temperature was calculated by the average of maximum and minimum temperature and $7^{\circ} \mathrm{C}$ was considered the base temperature for leaf emission in strawberries (ANTUNES et al., 2006). Equation of accumulated thermal time (ATT) was estimated by the sum of the daily thermal time.

Subsequently, a linear regression between the number of leaves (NL) of the main crown and the accumulated thermal time (ATT) was carried out and throughout the inverse of the angular coefficient of the linear regression, the phyllochron was estimated $\left({ }^{\circ} \mathrm{C}\right.$ day leaf $\left.{ }^{-1}\right)$. Results were submitted to a variance analysis to evaluate the interaction between factors and the means were compared by Tukey's test at 5\% of probability, using the Statistical Analysis System SAS version 9.0 (SAS INSTITUTE, 2002).

\section{RESULTS AND DISCUSSION}

The data for minimum and maximum daily temperatures, from May $19^{\text {th }}$ to December $15^{\text {th }}, 2012$, showed that the mean for the minimum temperature for the period was $17.9^{\circ} \mathrm{C}$ and the mean for the maximum was $19.3^{\circ} \mathrm{C}$ (Figure 1A). Considering the entire period, the mean temperature was $18.6^{\circ} \mathrm{C}$. For the same period, during the 2013 crop year, the mean temperature was $17.1^{\circ} \mathrm{C}$, with the higher value of $17.8^{\circ} \mathrm{C}$ (Figure 1B). Thus, it is possible to observe that for the second year of evaluation, which is 2013, the mean temperatures were $1.5^{\circ} \mathrm{C}$ lower than the ones observed during 2012.

Strawberry is a crop influenced by air temperature, according to ROBERT et al. (1999) and KUROKURA et al. (2013). Temperatures from 12 to $18^{\circ} \mathrm{C}$ favors the crop flowering and temperatures from 20 to $24^{\circ} \mathrm{C}$ favors the leaf and fruit development, conversely, stolon emission is favored by higher temperatures, above $24^{\circ} \mathrm{C}$. Thus, the observed temperatures during the experimental period, for 2012 and 2013, favored strawberry development at the studied region, and just few observations of lower temperature than the basal for the crop were registered (Figure 1).

According to the regression for number of leaves (NL) and accumulated thermal time (ATT), it is possible to observe a linear regression between the studied factors, with a determination coefficient of 0.99 and the means for NL and ATT for strawberries from different origins are shown on figure $2 \mathrm{~A}$ and 2B, for 2012. High correlation between factors, evidenced by the $r^{2}$ values observed in this experiment indicated that despite the photoperiod influence on crop development, the air temperature is the main factor that affects leaf emission, proving the high effectiveness of the method of the linear regression to estimate the phyllochron in strawberries, as observed by STRECK et al. (2005) and XUE et al. (2004).

Considering the value of total phyllochron for the strawberry cultivars, the variance analysis indicated that is there an interaction only between cultivar and origin, showing the influence of both factors on the evaluated variable. Thus, the crop year did not affect the evaluated variable.

Higher phyllochron values for 'Camarosa' and 'Camino Real' from both origins indicates that this cultivars presented lower leaf emission speed when compared to 'Albion', since the cultivars needs a higher number of degree-days for an emission of two successive leaves (Table 1). Similar results for these cultivars, that is not statistically different from each other, and not even in relation to origin, can be justified because they are known as short day cultivars. Cultivar 'Albion' presented significant difference for phyllochron values, presenting lower values for seedlings from Chile, with a reduction of $12.64^{\circ} \mathrm{C}$ day leaf ${ }^{-1}$, as shown on table 1 .

According to the results, it is possible to observe the importance of cold hours that neutral day seedlings received during nursery stage, since 'Albion' seedlings from Chile presented lower phyllochron values when compared to seedlings from Pelotas, which presented higher leaf emission ratio. In this sense, at vernalization is a factor that affects strawberry development, which is in accordance COSTA et al. (2014), and can confer anticipation of the culture cycle, and RONQUE (1998) related the crop yield with the number of cold hours received by seedlings at the nursery.

Cultivars from Pelotas, transplanted on May $19^{\text {th }}, 2012$, achieved an accumulated thermal time (sum) of $2,596.90^{\circ} \mathrm{C}$ during period of evaluation. Seedlings from Chile transplanted on June $5^{\text {th }}, 2012$, achieved an accumulated thermal time of $2,263.76^{\circ} \mathrm{C}$ during the evaluation period. Thus, it is possible to verify that seedlings from Chile achieved a lower thermal time, but the number on the main crown was similar when compared to seedlings from Pelotas, that achieved higher thermal time value during the evaluated period. 


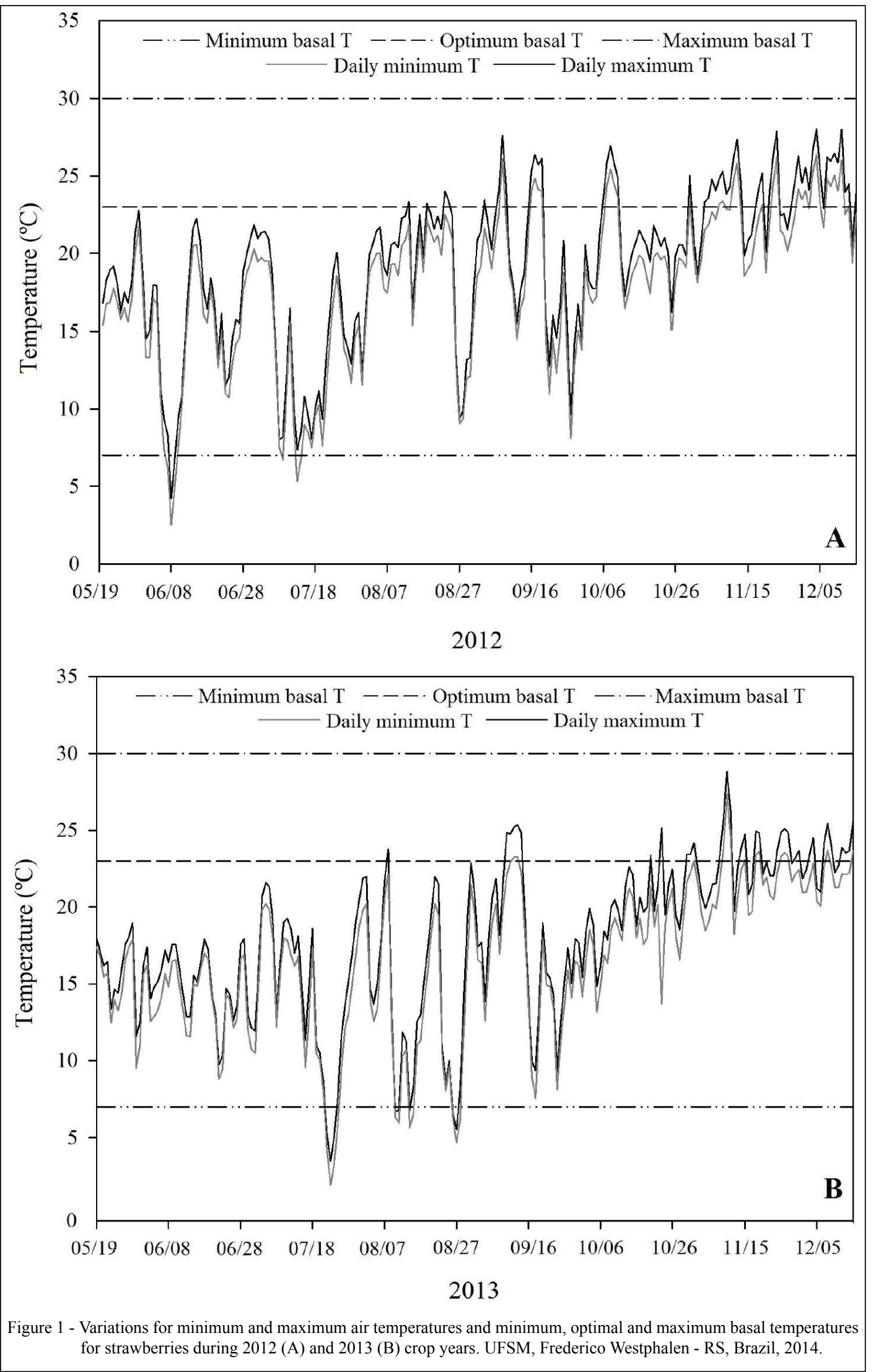

Ciência Rural, v.46, n.9, set, 2016. 

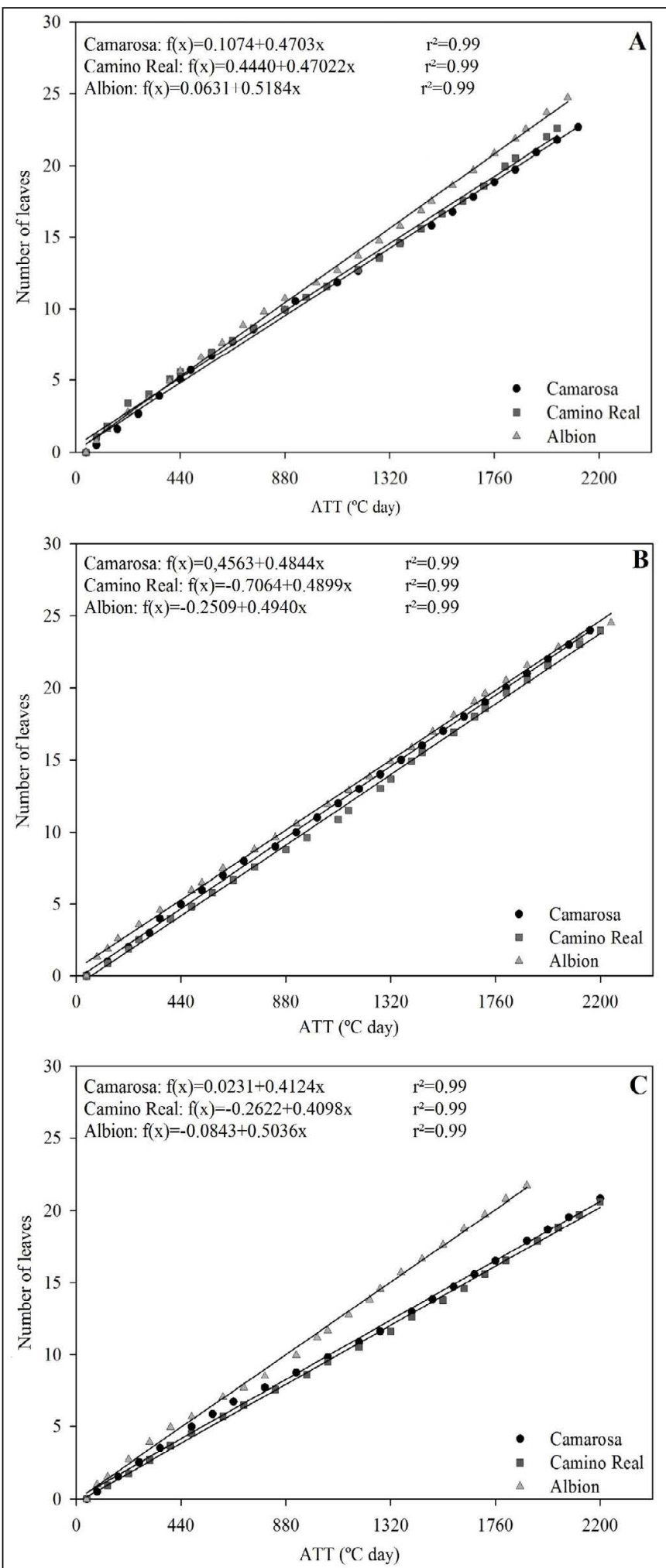

Figure 2 - Ratio between leaf number on main crown and the accumulated thermal time (ATT) of three strawberries cultivars according to seedlings origin: Pelotas (A) and Chile (B); and years 2012 (B) and 2013 (C) for seedlings from Chile. UFSM, Frederico Westphalen - RS, Brazil, 2014. 
Table 1 - Means for total phyllochron for three strawberries cultivars according to origin and crop year. UFSM, Frederico Westphalen - RS, Brazil, 2014.

\begin{tabular}{|c|c|c|c|c|}
\hline Cultivar & Chile & Pelotas & 2012 & 2013 \\
\hline 'Albion' & $91.18 \mathrm{bB}$ & $103.82 \mathrm{aA}$ & $98.28 \mathrm{aB}$ & $96.72 \mathrm{aB}$ \\
\hline 'Camarosa' & $103.97 \mathrm{aA}$ & $103.55 \mathrm{aA}$ & $101.76 \mathrm{aA}$ & $105.76 \mathrm{aA}$ \\
\hline 'Camino Real' & $101.65 \mathrm{aA}$ & $102.03 \mathrm{aA}$ & $100.40 \mathrm{aAB}$ & $103.27 \mathrm{aA}$ \\
\hline
\end{tabular}

"Means followed by the same lower case letters in the row and upper case in the column are not different according to Tukey's test at $5 \%$ of probability.

These results showed that, for the same cultivars, from different origins, there are differences on the necessary thermal time for the emission of the same number of leaves, and for the present study, seedlings from Pelotas needed more ${ }^{\circ} \mathrm{C}_{\text {day }}^{-1}$ for leaf emission.

On figure $2 \mathrm{~A}$ and $2 \mathrm{C}$ is possible to observe the means for number of leaves (NL) according to accumulated thermal time (ATT), for three cultivars ('Camarosa', 'Camino Real' and 'Albion') from Chile during 2012 and 2013 crop years. Considering leaf emission for different cultivars, it can be inferred that the cultivar 'Camarosa' presented higher phyllochron values, as observed for the same cultivar, for seedlings from different origins.

It is possible to observe that, for both years, the cultivar 'Albion' presented a lower phyllochron value, and this difference is more evident for the second year of evaluation (2013), when the difference from a late cultivar ('Camarosa') achieved $9.04^{\circ} \mathrm{C}$ day leaf ${ }^{-1}$ (Table 1). The values are in accordance to SANTOS (1999) that verified that for neutral day cultivars the leaf emission is continuous, when the air temperature is between 10 and $28^{\circ} \mathrm{C}$, as observed for the present study, shown on figure 1. COSTA et al. (2014), studying the same cultivar, observed phyllochron values of $93.3^{\circ} \mathrm{C}$ day leaf ${ }^{-1}$, for vernalized seedlings, and $117.8^{\circ} \mathrm{C}$ day leaf ${ }^{1}$, for seedlings without vernalization.

It is also possible to observe that lower minimum temperatures occurred during the vegetative period for 2012 and for 2013 this period is later, coinciding with flowering period and even with harvest period. As the emission of successive leaves ratio depends on temperature, is common the difference between phyllochron values during the crop cycle, varying according to the occurrence of maximum temperatures during plant development.

According to GALLETA \& HIMELRICK (1990), the emergency of two consecutive leaves in strawberries is observed between 8 and 12 days, and the temperature is the main factor during this physiological process. In this study, the interval between two successive leaves emission varied from 4 to 16 days.

\section{CONCLUSION}

In a general manner, the cultivars 'Camarosa' and 'Camino Real' (short day cultivars) need a higher degree Celsius accumulation in order to generate a leaf emission when compared to cultivar 'Albion' (neutral day cultivar), characterizing higher phyllochron values. For experimental conditions, the cultivar 'Albion' presented lower values of phyllochron and thus, higher leaf emission, being considered earlier. For origin, 'Albion' seedlings from Chile presented lower total phyllochron values. From seedlings from Pelotas, no difference between cultivars was observed.

No significant differences were observed according to crop year, but higher phyllochron values and lower leaf emission ratio were observed during 2013 for 'Camino Real' and 'Camarosa' cultivars. For both years, 2012 and 2013, lower amount of phyllochron for 'Albion' were observed, when compared to other cultivars.

\section{AKNOWLEDGMENTS}

The authors would like to thank the Coordenação de Aperfeiçoamento de Pessoal de Nível Superior (CAPES) for the scholarship.

\section{REFERENCES}

ANTUNES, O.T. et al. Blooming, fruit set, and fruit maturation of strawberry growing in protected environment. Horticultura Brasileira, Brasília, v.24, n.4, p.426-430, 2006. Available from: 
$<$ http://www.scielo.br/pdf/hb/v24n4/06.pdf $>$. Accessed: Nov. 13, 2013. doi: 10.1590/S0102-05362006000400006.

ARNOLD, C.Y. Maximum-minimum temperatures as a basis for computing heat units. Proceedings of the American Society for Horticultural Sciences, Genova, v.76, p.682-692, 1960.

COSTA, R.C. et al. Phenology and leaf accumulation in vernalized and non-vernalized strawberry seedligs in neutral-days. Acta Scientiarum, Maringá, v.36, n.1, p.57-62, 2014. Available from: $<$ http://www.scielo.br/pdf/asagr/v36n1/v36n1a09.pdf $>$. Accessed: Dec. 18, 2014. doi: 10.4025/actasciagron.v36i1.17285.

EMPRESA BRASILEIRA DE PESQUISA AGROPECUÁRIA (EMBRAPA). Sistema Brasileiro de classificação de solos. 3.ed. Brasília, 2013. 353p.

GALLETA, G.; HIMELRICK, D. Strawberry management: small fruit crop management. Englewood Cliffs: Prentice-Hall, 1990. 602p.

GILMORE, E.C.; ROGERS, J.S. Heat units as a method of measuring maturity in corn. Agronomy Journal, Madison, v.50, n.10, p.611-615, 1958 .

INSTITUTO NACIONAL DE METEOROLOGIA (INMET) Dados climáticos da Estação de Frederico Westphalen. Banco de dados do Instituto Nacional de Meteorologia. Online. Available from: <http://www.inmet.gov.br>. Accessed: 2012-2013.

KLEPPER, B. et al. Quantitative characterization of vegetative development in small cereals. Agronomy Journal, Madison, v.74, n.5, p.789-792, 1982.

KÖPPEN, W.; GEIGER, R. Klimate der Erde. Gotha: Verlag Justus Perthes. 1928. Wall-map $150 \mathrm{~cm}$ x $200 \mathrm{~cm}$.

KUROKURA, T. et al. The regulation of seasonal flowering in the Rosaceae. Flowering Newsletter Review. Journal of Experimental Botany, Lancaster, v.64, n.14, p.4131-4141, 2013. Available from: <http://jxb.oxfordjournals.org/content/ early/2013/08/08/jxb.ert233.full.pdf + html $>$. Accessed: Dec. 18, 2013. doi: $10.1093 / \mathrm{jxb} / \mathrm{ert} 233$.

McMASTER, G.S.; WILHELM, W.W. Growing degree-days: one equation, two interpretations. Agricultural and Forest Meteorology, Amsterdam, v.87, n.4, p.291-300, 1997. Available from: <http:// www.sciencedirect.com/science/article/pii/S0168192397000270>. Accessed: Sept. 20, 2013. doi: 10.1016/S0168-1923(97)00027-0.

OLIVEIRA, R.P.; SCIVITTARO, W.B. Production of strawberry fruits depending on vernalization periods of the transplants. Horticultura Brasileira, Brasília, v.27, n.1, p.091095, 2009. Available from: <http://www.scielo.br/pdf/hb/ v27n1/18.pdf $>$. Accessed: Sept. 10, 2013. doi: 10.1590/S010205362009000100018 .

ROBERT, F. et al. Photoperiod and temperature effect on growth of strawberry plant (Fragaria $\times$ ananassa Duch.): development of a morphological test to assess the dormancy induction. Scientia Horticulturae, Amsterdam, v.82, p.217-226, 1999. Available from: $<$ http://www.sciencedirect.com/science/article/pii/ S0304423899000540>. Accessed: Sept. 10, 2013. doi: 10.1016/ S0304-4238(99)00054-0.

ROSA, H.T. et al. Base temperature for leaf appearance and phyllochron of selected strawberry cultivars in a subtropical environment. Bragantia, Campinas, v.70, n.4, p.939-945, 2011. Available from: <http://www.scielo.br/pdf/brag/v70n4/29.pdf $>$. Accessed: Sept. 14, 2013. doi: 10.1590/S0006-87052011000400029.

SANTOS, A.M. Melhoramento genético do morangueiro. Informe Agropecuário, Belo Horizonte, v.20, n.198, p.24-29, 1999

SAS INSTITUTE. SAS user's guide: statistics. Cary, NC, 2002. Version 9.0

SERÇE, S.; HANCOCK, J.F. The temperature and photoperiod regularion of flowering and runnering in the strawberries, Fragaria chiloensis, F. virginiana, and F. x ananassa. Scientia Horticulturae, Amsterdam, v.103, p.167-177, 2005. Available from: <http:// www.sciencedirect.com/science/article/pii/S0304423804001025> Accessed: Sept. 10, 2013. doi: 10.1016/j.scienta.2004.04.017.

STRECK, N.A. et al. Estimating the plastochron in muskmelon (Cucumis melo L.) grown inside plastic greenhouse at different planting dates. Ciência Rural, Santa Maria, v.35, n.6, p.1275-1280, 2005. Available from: $<$ http://www.scielo.br/scielo.php?script=sci arttext\&pid=S0103-84782005000600008 $>$. Accessed: Sept. 10, 2013. doi: 10.1590/S0103-84782005000600008.

STRECK, N.A. et al. Improving predictions of developmental stages in winter wheat: a modified Wang and Engel model. Agricultural and Forest Meteorology, Amsterdam, v.115, n.3-4, p.139-150, 2003. Available from: <http://www-sciencedirect-com.ez66. periodicos.capes.gov.br/science/article/pii/S0168192302002289>. Accessed: Aug. 14, 2013. doi: 10.1016/S0168-1923(02)00228-9.

XUE, Q. et al. Predicting leaf appearance in field-grown winter wheat: evaluating linear and non-linear models. Ecological Modeling, Amsterdam, v.175, p.261-270, 2004. Available from: $<\mathrm{http}$ ://www-sciencedirect-com.ez66.periodicos.capes.gov.br/ science/article/pii/S0304380003004800>. Accessed: Aug. 14, 2013. doi: 10.1016/j.ecolmodel.2003.10.018. 